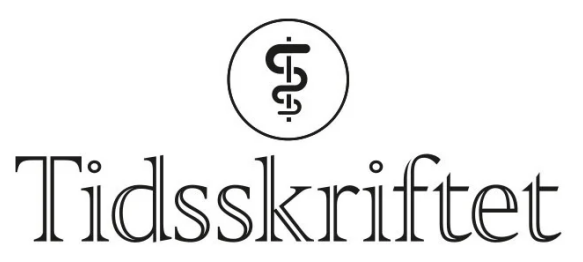

DEN NORSKE LEGEFORENING

\title{
Vi må ikke glemme vaksinene mot andre sykdommer
}

DEBATT

\section{HANNE DAHL VONEN}

hanne.d.vonen@ntnu.no

Hanne Dahl Vonen er medisinstudent ved NTNU og nasjonal styrerepresentant i Norsk medisinstudentforening.

Forfatteren har fylt ut ICMJE-skjemaet og oppgir ingen interessekonflikter.

\section{MARTA RØTTINGEN ENDEN}

Marta Røttingen Enden er medisinstudent ved Universitetet i Bergen og nasjonal menneskerettighetsansvarlig i Norsk medisinstudentforening. Forfatteren har fylt ut ICMJE-skjemaet og oppgir ingen interessekonflikter.

\section{Vaksinasjon mot koronavirus må ikke gå på bekostning av andre essensielle vaksinasjonsprogram.}

Håndtering av covid-19-pandemien, vaksineutvikling og vaksinefordeling er høyaktuelt og viktig. Tilgang på og bruk av de godkjente vaksinene mot koronavirusinfeksjon bidrar både til å forebygge alvorlig sykdom og å fremskynde en sårt tiltrengt gjenåpning av samfunnet. Det er ikke feil å fokusere på dette, men likefullt er det viktig at vi ikke trapper ned på arbeidet med å bekjempe andre alvorlige infeksjonssykdommer.

Årlig dør 1,5 millioner barn av sykdommer som i utgangspunktet lar seg forebygge, som polio, meslinger og stivkrampe (1). Flere steder har situasjonen blitt verre under covid-19pandemien $(\underline{2}, 3)$. Nedstengning av samfunn har vært nødvendige smittevernstiltak i en rekke land, men dessverre har det bidratt til å sette en stopper for utallige vaksinasjonsprogram. Som et resultat av dette lever nå 80 millioner barn med en risiko for å få potensielt dødelige sykdommer som kunne vært forebygget med en vaksine (4.).

«Nå lever 80 millioner barn med en risiko for å få potensielt dødelige

sykdommer som kunne vart forebygget med en vaksine»

På det afrikanske kontinentet sør for Sahara er det til nå i pandemien meldt om ca. 6o ooo koronavirusrelaterte dødsfall, hvorav litt over 50 ooo i Sør-Afrika (5). En del av forklaringen på dette relativt lave tallet kan ligge i manglende testkapasitet. Andre antatte forklaringer er blant annet knyttet til en yngre befolkning og varmere klima (ㅁ). Men i likhet med andre 
katastrofer bidrar pandemien til å sette den eksisterende helsehjelpen under press. I Den demokratiske republikken Kongo har man sett at arbeidet med pandemien har fått konsekvenser for meslingresponsen (7.). Centers for Disease Control and Prevention estimerer at på verdensbasis risikerer mer enn 117 millioner barn å gå glipp av meslingvaksinen ( $\underline{8})$. Dette er store tall. Likevel får denne problematikken relativt lite oppmerksomhet i media.

Som del av det internasjonale samfunnet har Norge et ansvar for å sørge for å forebygge tidlig død og sikre at alle verdens land kan dra nytte av vaksiner, uavhengig av egne ressurser. Vaksiner er et svært kostnadseffektivt tiltak: For hver dollar som investeres i vaksiner, får man som samfunn i lav - og mellominntektsland 16 dollar tilbake grunnet innsparte helseutgifter og økt produktivitet (9). Vaksiner forebygger ikke bare sykdom hos enkeltindivider, vaksinasjonsprogrammer er også viktig for samfunnsutviklingen.

Vaksiner, som er tidenes kanskje viktigste verktøy for å bedre den globale folkehelsa, redder

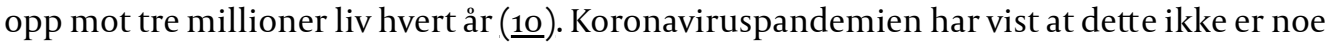
vi kan ta for gitt, og at vi fremdeles har en vei å gå før vaksiner er et tilgjengelig gode for alle.

\section{LITTERATUR}

1. UNICEF. UNICEF reaches almost half of the world's children with life-saving vaccines. https://www.unicef.org/press-releases/unicef-reaches-almost-half-worlds-children-life-savingvaccines/ Lest 6.4.2021.

2. Levels \& Trends in Child Mortality. Report 2020. New York, NY: UNICEF, 2020. https://www.unicef.org/media/79371/file/UN-IGME-child-mortality-report-2020.pdf Lest 20.4.2021.

3. WHO. UNICEF. Emergency Call to Action for Measles and Polio Outbreak Prevention and Response. https://polioeradication.org/wp-content/uploads/2020/11/Call-To-Action-20201105.pdf Lest 20.4.2021.

4. UNICEF. Immunization coverage: Are we losing ground? https://data.unicef.org/resources/immunization-coverage-are-we-losing-ground/ Lest 6.4.2021.

5. Africa CDC. Coronavirus Disease 2019 (COVID-19): Latest updates on the COVID-19 crisis from Africa CDC. https://africacdc.org/covid-19/ Lest 10.4.2021.

6. Rice BL, Annapragada A, Baker RE et al. Variation in SARS-CoV-2 outbreaks across sub-Saharan Africa. Nat Med 2021; 27: 447-53. [PubMed][CrossRef]

7. Leger Uten Grenser. Stort meslingutbrudd herjer i DR Kongo. https://legerutengrenser.no/glemtekriser/meslingutbrudd-i-kongo.html Lest 20.4.2021.

8. Centers for Disease Control and Prevention. COVID-19's Impact on Measles Vaccination Coverage. https://www.cdc.gov/globalhealth/measles/news/covid-impact-on-measles-vaccination.html Lest 20.4.2021.

9. GAVI. Cost-Effective: Public Health's Best Buy. https://www.gavi.org/vaccineswork/valuevaccination/cost-effective Lest 6.4.2021.

10. WHO. Immunization coverage: Key Facts. https://www.who.int/en/news-room/factsheets/detail/immunization-coverage Lest 6.4.2021.

Publisert: 5. mai 2021. Tidsskr Nor Legeforen. DOI: 10.4045/tidsskr.21.0314

Mottatt 13.4.2021, godkjent 21.4.2021.

(C) Tidsskrift for Den norske legeforening 2023. Lastet ned fra tidsskriftet.no 26. april 2023. 